\title{
OBRAZ ZJEDNOCZONEJ EUROPY W KONCEPCJACH PRZEDSTAWICIELI OPOZYCJI ANTYFASZYSTOWSKIEJ WE WŁOSZECH W LATACH 1943-1945
}

ABSTRACT Picture of united Europe in the concepts of Italian anti-fascist opposition members in 1943-1945

The article presents concepts of united Europe created by representatives of different fractions of the anti-fascist Italian opposition in the period of the so-called Resistenza (1943-1945), with particular focus on the stances of left-wing groups. The fullest theoretical foundations of federalist concepts created during the Second World War come from the Ventotene Manifesto (the so-called Manifesto for Free and United Europe), elaborated at the turn of June and July of 1941 by charismatic leaders of Movimento Federalista Europeo - Altiero Spinelli and Ernesto Rossi - in collaboration with Eugenio Colorni. Influenced by English federalists from Federal Union, Spinelli and Rossi were pointing to the crisis of a nation state and its results - nationalism, imperialism and fascism. The authors were convinced that the only way to ensure continued peace in Europe was to create a European federation, comprised entirely of democratic states. The idea of the United States of Europe was advocated also by a liberal lawyer and economist, later the Governor of the Bank of Italy and the President of Italy, Luigi Einaudi. In his articles and political writings regularly published from 1918 until the end of the WWII Einaudi criticised the League of Nations as a weak institution lacking in authority and unable to effectively challenge the imperialist tendencies of some of its members. He sought the reasons for this weakness in the very structure of the League of Nations, i.e. in the confederation model. In studies published between 1943 and 1945 the liberal politician emphasised interdependencies between economy and politics. Einaudi identified 
the idea of a sovereign national state and the doctrine of nationalism as main enemies of the European federalism. Another politician advocating limiting sovereignty of national states in the name of broad solidarity between free European nations was a leader of Christian Democracy and the Prime Minister of Italy between 1945 and 1953 - Alcide De Gasperi. He underlined the significance of cooperation with the United States of America and the United Kingdom of Great Britain in the process of peace-rebuilding. Unlike Spinelli and Rossi, the leader of Christian Democracy did not support the federation model of integration - De Gasperi placed emphasis on the gradual character of this process and on the need for finding "transitional solutions", similarly to Einaudi, pointing to the significance of the economic aspect.

Key words: European federalism, national state, Resistenza, Italy, Ventotene Manifesto, Altiero Spinelli, Ernesto Rossi, Luigi Einaudi, Alcide De Gasperi

Słowa kluczowe: federalizm europejski, państwo narodowe, Resistenza, Włochy, Manifest z Ventotene, Altiero Spinelli, Ernesto Rossi, Luigi Einaudi, Alcide De Gasperi

$\mathrm{O}$ kres międzywojenny oraz lata II wojny światowej obfitowały w powstawanie projektów integracji europejskiej. We Włoszech koncepcje te rozwinęły się przede wszystkim w kręgu opozycji antyfaszystowskiej. Od zakończenia I wojny światowej ideę Stanów Zjednoczonych Europy głosili m.in.: Luigi Einaudi, Giovanni Agnelli, Attilio Cabiati, Carlo Sforza, Filippo Turati, Claudio Treves, Giuseppe Emanuele Modigliani oraz Carlo Rosselli. Wkład wspomnianych włoskich teoretyków w rozwój doktryny federalizmu europejskiego nie został dotąd szerzej opracowany w polskiej literaturze przedmiotu. Celem niniejszego artykułu jest przedstawienie wizji zjednoczonej Europy różnych odłamów opozycji antyfaszystowskiej, ze szczególnym uwzględnieniem stanowisk przedstawicieli ugrupowań lewicowych, liberalnych oraz katolickich w latach 1943-1945. Ostatnie dwa lata II wojny światowej, kiedy nastąpiła konsolidacja środowisk opozycji antyfaszystowskiej oraz ukształtował się w północnych Włoszech antyfaszystowski Ruch Oporu, tzw. Resistenza, były zarazem okresem, w którym powstały najdojrzalsze koncepcje zjednoczenia Europy ${ }^{1}$. Owe programy federacyjne, które rozwinęły się często w warunkach emigracji politycznej lub zesłania i represjonowania ich twórców przez faszystowski reżim, stały się następnie ważnym punktem odniesienia dla procesów integracyjnych, realizowanych po zakończeniu II wojny światowej.

1 Jak słusznie zauważył włoski filozof Norberto Bobbio, niecaly włoski Ruch Oporu miał charakter federalistyczny. Federalizm był jednak wspólnym mianownikiem różnych grup, które wzięly aktywny udział w wojnie wyzwoleńczej lat 1943-1945. Zob. N. Bobbio, Il federalismo nel dibattito politico e culturale della Resistenza, [w:] L'idea dell'unificazione europea dalla prima alla seconda guerra mondiale, red. S. Pistone, Torino 1975, s. 235-236, Studi / Fondazione Luigi Einaudi. 


\section{EUROFASZYZM A KONCEPCJE EUROPEJSKIE I FEDERALISTYCZNE OPOZYCJI ANTYFASZYSTOWSKIEJ}

Włoski faszyzm, który doszedł do władzy w następstwie Marszu na Rzym 28 października 1922 r., był negatywnie ustosunkowany do doktryny federalizmu europejskiego. Jego antypacyfistyczna, antydemokratyczna, imperialistyczna i skrajnie nacjonalistyczna ideologia stanowiła negację zasad pokoju, solidarności oraz równości poszczególnych narodów i państw europejskich, na których opierają się praktycznie wszystkie projekty integracyjne, począwszy od XIX w. W drugim rozdziale swej książki Dottrina del fascismo, która ukazała się w 1932 r., Benito Mussolini głosił: doktryna faszyzmu nie wierzy w możliwość i użyteczność utrzymania wiecznego pokoju. Odrzuca pacyfizm, który stanowi negację walki i poświęcenia ${ }^{2}$. Jak słusznie zauważył krakowski politolog Wiesław Kozub-Ciembroniewicz, polityka dążenia do mocarstwowości i ekspansji narodowej była pojmowana przez duce jako wyraz siły witalnej faszystowskiego państwa. Podobnie też doktryna wywodząca się od przyjętego a priori „postulatu pokoju” była uważana za nie do pogodzenia z ideologią faszystowską ${ }^{3}$. Dopiero z początkiem lat 30 . XX w. rozwinęła się doktryna eurofaszyzmu, głosząca mit europejskiego imperium, którego stolica powinna znajdować się w Rzymie jako centrum nowej, uniwersalnej cywilizacji, opartej na ideologii faszystowskiej oraz doktrynie korporacjonizmút. Należy pamiętać, że przedstawiona w programie eurofaszyzmu europejska wspólnota faszystowska, która w najbardziej radykalnych koncepcjach przybierała postać paneuropejskiej federacji narodów faszystowskich, o charakterze zarówno antykapitalistycznym, jak i antykomunistycznym, miała też silne konotacje imperialistyczne ${ }^{5}$. W latach 1943-1945, obok wspomnianej koncepcji stworzenia nowej cywilizacji, rozwinęły się dwa inne prądy ideowe: 1) tzw. technokratyczny (reprezentowany m.in. przez Pietro Vaccariego i Gaetano Pietrę), postulujący porzucenie koncepcji stworzenia dwóch oddzielnych przestrzeni życiowych dla Niemiec i Włoch na rzecz zbudowania federacji państw europejskich, charakteryzującej się samowystarczalnością gospodarczą, wolną wymianą handlową, wspólnymi finansami oraz wspólnym programowaniem ekonomicznym na poziomie kontynentalnym, umożliwiającym harmonijny rozwój poszczególnych regionów; 2) idealistyczno-pozytywny (Giuseppe Bottaiego i Camillo Pellizziego), głoszący

2 Doktryna faszyzmu ukazała się w 14 tomie Enciclopedia italiana w 1932 r., a następnie została opublikowana w 8 tomie Scritti e Discorsi di Benito Mussolini w 1934 r. Zob. W. Kozub-Ciembroniewicz, Doktryny wtoskiego faszyzmu i antyfaszyzmu w latach 1922-1939, Kraków 1992, s. 76, Zeszyty Naukowe Uniwersytetu Jagiellońskiego, 1068, Prace z Nauk Politycznych, z. 45.

3 W latach 20. Mussolini, nie szczędząc krytyki Lidze Narodów, podkreślał, iż faszyzmowi obce są wszelkie konstrukcje o charakterze międzynarodowo-zrzeszeniowym, tamże, s. 84.

4 Polski historyk Jerzy Wojciech Borejsza wiąże początek eurofaszyzmu z momentem dojścia do władzy w Niemczech Adolfa Hitlera w styczniu 1933 r. i utworzeniem w lipcu 1933 r. tzw. CAUR - Comitati d'Azione per l'Universalità di Roma. Zob. J.W. Borejsza, Szkoty nienawiści. Historia faszyzmów europejskich 1919-1945, Wrocław 2000, s. 98.

5 D. Cofrancesco, Il mito europeo del fascismo (1939-1945), „Storia Contemporanea” 1983, II, s. 28-29. 
postulat zbudowania unii narodów europejskich, pojmowanej nie tylko jako projekt ekonomiczno-polityczny, lecz także moralny i kulturowy ${ }^{6}$.

Diametralnie odmienne koncepcje zjednoczonej Europy powstały w okresie dwudziestolecia międzywojennego w środowiskach liberalnych, chadeckich i socjalistycznych, które pomimo zasadniczych różnic ideologicznych łączyły idea walki z totalitarnym reżimem oraz przekonanie o konieczności integracji kontynentu europejskiego w oparciu o zasady wolności, demokracji i pokoju. To właśnie w kręgu opozycji antyfaszystowskiej ${ }^{7}$ wykrystalizowały się już w latach 20. XX w. idee zbudowania Stanów Zjednoczonych Europy, połączone z krytyką nacjonalizmu, imperializmu oraz faszyzmu. Jeszcze przed zakończeniem I wojny światowej koncepcje federacji europejskiej rozwijał w swoich artykułach opublikowanych w „Corriere della Sera” liberalny ekonomista Luigi Einaudi, a także Giovanni Agnelli i Attilo Cabiati w książce pt. Federacja europejska czy Liga Narodów? Einaudi, podobnie jak Agnelli i Cabiati, głosił potrzebę integracji europejskiej, krytykując jednocześnie Ligę Narodów jako instytucję zbyt słabą, żeby przeciwstawić się imperialistycznym dążeniom swoich członków. Podobnie też liberalny senator, dyplomata i polityk Carlo $S$ forza ${ }^{8} \mathrm{w}$ książce pt. O federazione europea o nuova guerra przedstawił w 1921 r. krytykę nacjonalizmów, które uważał za deformację prawdziwego patriotyzmu. Sforza postulował jedność polityczną kontynentu europejskiego w formie federacji, podkreślając, że powojenna Europa, pełna podziałów i wzajemnych pretensji, była jedynie kopciuszkiem wobec potęgi Stanów Zjednoczonych Ameryki. W latach 30. koncepcje federalistyczne doszły także do głosu w reformistycznym skrzydle partii socjalistycznej. W pismach Filippo Turatiego, Silvio Trentina i Carlo Rossellego pojawiają się krytyka państwa narodowego pojmowanego jako zarzewie nacjonalizmów i imperializmów oraz przekonanie o konieczności zbudowania

Tamie, s. 25.

Opozycja antyfaszystowska zawiązała się po zamordowaniu przez faszystów posła socjalistów unitarystów Giacomo Matteottiego w czerwcu 1924 r. Część parlamentarzystów podjęła wówczas decyzję o opuszczeniu wspólnych obrad Izby do czasu wyjaśnienia sprawy Matteottiego. Ta secesja, nazwana „awentyńską", objęła liberalnych demokratów (pod przywództwem Giovanniego Amendoli), socjalistów Filippo Turatiego, popularów z Alcide De Gasperim na czele i komunistów. Ostatecznie opozycja nie opracowała wspólnego modus operandi, nie otrzymała też poparcia ani ze strony Watykanu, ani króla Wiktora Emanuela, a komuniści dość szybko zrezygnowali z udziału w niej. W dniu 3 stycznia 1925 r. Mussolini, pod nieobecność posłów Awentynu, wygłosił w Izbie Deputowanych pamiętne przemówienie, gdzie zapowiedział wprowadzenie państwa totalnego i zdelegalizowanie wszystkich partii oraz ugrupowań poza partią faszystowską. W wyniku tego posunięcia opozycja została zlikwidowana w parlamencie, a większość czołowych polityków antyfaszystowskich, chcąc uniknąć więzienia, udała się na emigrację. Do ponownej konsolidacji środowisk antyfaszystowskich doszło dopiero po upadku Mussoliniego 25 lipca 1943 r., w wyniku powstania 9 września 1943 r. Komitetu Wyzwolenia Narodowego, złożonego z przedstawicieli sił antyfaszystowskich: socjalistów, liberałów, chrześcijańskich demokratów, nowo powstałej Partii Czynu, a także komunistów.

8 Carlo Sforza (1872-1952) był ministrem spraw zagranicznych Włoch w latach 1920-1921 i ponownie w latach 1947-1951. Po dojściu Mussoliniego do władzy w październiku 1922 r. zrezygnował z funkcji ambasadora Włoch w Paryżu i od 1927 r. przebywał na emigracji kolejno we Francji, Belgii, Wielkiej Brytanii i Stanach Zjednoczonych. Był jednym z honorowych przewodniczących Kongresu Paneuropejskiego, który odbył się w Wiedniu 4 października 1926 r. Entuzjastycznie przyjął też Plan Branda przedstawiony na posiedzeniu Ligi Narodów 5 września 1929 r. 
federacji europejskiej, będącej jedyną drogą dla zapewnienia trwałego pokoju i bezpieczeństwa na kontynencie europejskim? ${ }^{9}$ W szczególności Filippo Turati, jeden z założycieli Włoskiej Partii Socjalistycznej (Partito Socialista Italiano - PSI), przebywający od 1926 r. na emigracji politycznej we Francji, biorąc udział w sondażu na temat zjednoczonej Europy przeprowadzonym przez paryską gazetę „Le Quotidien” w 1929 r., podkreślił potrzebę utworzenia Stanów Zjednoczonych Europy, zauważając, że socjaliści nie byli przeciwnikami integracji europejskiej, gdyż z definicji byli internacjonalistami. Lider socjalistów unitarystów uważał, że przeszkodą na drodze do integracji były bezsensowne konflikty i nienawiść, które rozwinęły się pomiędzy poszczególnymi narodami europejskimi po zakończeniu I wojny światowej, a zarazem powstające w Europie autorytarne i totalitarne dyktatury. Turati był głęboko przekonany o konieczności integracji zarówno politycznej, jak i gospodarczej kontynentu i podkreślał znaczenie współpracy gospodarczej Europy ze Stanami Zjednoczonymi, dostrzegając niebezpieczeństwo ze strony imperialistycznej polityki Japonii. W 1929 r. socjalistyczny polityk pozytywnie odniósł się do Planu Brianda, apelując jednocześnie do demokratów europejskich, żeby nie zgodzili się na przystąpienie do wspólnoty europejskiej reżimów faszystowskich. Będąc zdecydowanym wrogiem wszelkich dyktatur, określał faszyzm jako anty-Europę. Jego zdaniem tylko federacja europejska mogła być dla Włoch okazją do zrzucenia jarzma faszyzmu. Dał wyraz tej koncepcji w swoim ostatnim przemówieniu wygłoszonym na spotkaniu Międzynarodówki Socjalistycznej w Wiedniu w 1931 r., gdzie stwierdził m.in., iż należy zbudować Europę, żeby odbudować Włochy. Turati rozważał dwie możliwe hipotezy kształtu przyszłej federacji: 1) utworzenie Stanów Zjednoczonych bez państw niedemokratycznych lub 2) powstanie tzw. „fałszywych Stanów Zjednoczonych", z udziałem państw rządzonych przez dyktatorów.

\section{IDEE FEDERACJI EUROPEJSKIEJ PRZEDSTAWICIELI ANTYFASZYSTOWSKICH ŚRODOWISK LEWICOWYCH}

W czasie II wojny światowej w środowisku włoskich antyfaszystów nastąpiła dalsza konsolidacja idei zjednoczonej Europy. Najpełniejszą podbudowę teoretyczną osiągnęly one w postaci Manifestu $z$ Ventotene (tzw. Manifestu dla wolnej i zjednoczonej Europy), opracowanego na przełomie czerwca i sierpnia 1941 r. przez Altiero Spinellego i Ernesto Rossiego, przy współpracy socjalistycznego filozofa i matematyka pochodzenia żydowskiego Eugenio Colorniego ${ }^{10}$. Główny autor Manifestu, Altiero Spinelli, w młodości związany z Partią Komunistyczną, a po wojnie charyzmatyczny przywódca

Należy wspomnieć: Gli Stati Uniti d'Europa e il Fascismo Filippo Turatiego z 1929 r., Riflessioni sulla crisi e sulla rivoluzione Silvio Trentina z 1933 r. oraz wydane w tajnym obiegu przez Partię Czynu w 1945 r. Stato, Nazione, Federalismo, a także Europeismo o Fascismo Carlo Rossellego z 1935 r.

10 Eugenio Colorni (1909-1944) - aktywny działacz Giustizia e Libertà, w 1938 r. został zaaresztowany i po roku więzienia skierowany na wyspę Ventotene. W 1941 r. przeniesiono go do Melfi, skąd uciekł w 1943 r. i działał w ruchu oporu w Rzymie, gdzie został ciężko zraniony przez oddział faszystów 28 maja 1944 r. Zmarł 30 maja 1944 r. 
europejskiego ruchu federalistycznego ${ }^{11}$, jak sam wspominał w swoich pamiętnikach ${ }^{12}$, zbliżył się do koncepcji federalistycznych pod wpływem ekonomisty Ernesto Rossiego $^{13}$, którego poznał w czasie zesłania na wyspie Ventotene. Dzięki Rossiemu miał okazję zapoznać się z twórczością polityczną federalistów angielskich, przede wszystkim związanych z powstałą w 1938 r. grupą Federal Union (Lionela Robbinsa, Lorda Lothiana i Barbary Wootton), którzy wywarli duży wpływ na jego formację intelektual$\mathrm{ną}^{14}$, a także przeczytać pisma Luigiego Einaudiego. Jak zauważył Lucio Levi, od federalistów angielskich Spinelli przejął w szczególności przekonanie o istnieniu ścisłej relacji pomiędzy współczesnym kryzysem systemu europejskiego oraz imperializmem, a także przeświadczenie o zdegenerowaniu autorytarnym państw narodowych. Pod wpływem koncepcji przedstawicieli Federal Union Spinelli umocnił się w przeświadczeniu, że federacja europejska była jedynym środkiem umożliwiającym pokonanie anarchii międzynarodowej oraz zapewnienie pokoju.

Manifest $z$ Ventotene powstał na przełomie lipca i sierpnia 1941 r. i był owocem dyskusji prowadzonych przez Spinellego, Rossiego oraz Colorniego. Został opublikowany w 1943 r. jako pierwszy z zeszytów Europejskiego Ruchu Federalistycznego „L'Unità Europea”, wkrótce po utworzeniu Movimento Federalista Europeo w dniach

11 Jeden z głównych teoretyków federalizmu europejskiego Altiero Spinelli (1907-1986) wywodził się z rodziny o tradycjach socjalistycznych i laickich. Wczesne dzieciństwo spędził w Ameryce Południowej, gdzie jego ojciec pełnił funkcję wicekonsula. Powrócił do kraju w 1912 r. i ukończył studia prawnicze na uniwersytecie La Sapienza w Rzymie. W młodości zafascynowany twórczością Marksa i Engelsa, wstąpił do partii komunistycznej w 1924 r., wkrótce po zabójstwie Giacomo Matteottiego. W 1927 r. został zaaresztowany w Mediolanie przez policję faszystowską i skazany przez Trybunał Specjalny (Nadzwyczajny Trybunał Bezpieczeństwa Państwa) na 16 lat i 8 miesięcy więzienia. Ostatecznie spędził w więzieniu 10 lat, z czego ostatnie 6 na zesłaniu (dwa w Ponzy i 4 na wyspie Ventotene, gdzie w 1941 r. napisał wraz z Ernesto Rossim słynny Manifest). W 1937 r., przebywając w więzieniu, został wyrzucony z partii komunistycznej za „drobnomieszczańskie odchylenia ideologiczne”. W połowie 1944 r. przyłączył się do Partii Czynu (Partito d'Azione). Gorąco popierał projekt stworzenia Europejskiej Wspólnoty Obronnej. Był założycielem Instytutu Spraw Międzynarodowych w Rzymie, a w latach 1970-1976 - członkiem Komisji Europejskiej. W 1979 r. uzyskał mandat posła do Parlamentu Europejskiego. W 1980 r., wraz z innymi posłami do Parlamentu Europejskiego o poglądach federalistycznych, założył Klub Krokodyla, który opowiadał się za opracowaniem nowego traktatu europejskiego, pomyślanego jako konstytucja dla Europy. Traktat ustanawiający Unię Europejską, czyli tzw. Plan Spinellego, został przyjęty przez Parlament Europejski 14 lutego 1984 r. przeważającą większością głosów i stał się podstawą dla Jednolitego aktu europejskiego z $1986 \mathrm{r}$.

12 Zob. A. Spinelli, Come ho tentato di diventare saggio, Bologna 1984, s. 307-311, Storia / Memoria.

13 Jak wynika z listu napisanego do matki z 30 kwietnia 1937 r., Rossi miał już wówczas wstępnie opracowany projekt Stanów Zjednoczonych Europy, który następnie wprowadził do Manifesto di Ventotene. Szerzej na ten temat zob. A. Braga, Un federalista giacobino. Ernesto Rossi pioniere degli Stati Uniti d'Europa, Bologna 2007, s. 146-147, Fonti e Studi sul Federalismo e sull'Integrazione Europea - CRIE. Ricerche di Storia.

14 W swoich wspomnieniach Spinelli pisał: Ponieważ poszukiwatem jasności i precyzji myśli, moją uwage przyciagnąt nie mglisty, zawity i niespójny federalizm ideologiczny Proudhona i Mazziniego, który zakorzenit się we Francji i we Wtoszech, lecz precyzyjna i antydoktrynalna myśl federalistów angielskich tworzacych w latach 30., którzy proponowali przeszczepienie do Europy wspaniatych politycznych doświadczeń amerykańskich. Zob. A. Spinelli, Il lungo monologo, Roma 1968, s. 135. 
27-28 sierpnia 1943 r. w Mediolanie ${ }^{15}$. Drugie wydanie, tzw. rzymskie z 1944 r., opatrzone wstępem Colorniego pt. Problemi della Federazione Europea, zostało uzupełnione o dwa artykuły Spinellego, napisane na przełomie 1942 i 1943 r., pt. Gli Stati Uniti d'Europa e le varie tendenze politiche i politica marxista e politica federalista ${ }^{16}$. Manifest dzieli się na trzy części: 1) Kryzys cywilizacji wspótczesnej, 2) Zadania powojenne - jedność europejska i 3) Powojenne zobowiąania - reforma spoteczeństwa. Punktem wyjścia rozważań Spinellego i Rossiego jest przekonanie o kryzysie państw narodowych, połączone z krytyką nacjonalizmu, imperializmu i faszyzmu. Wspomniani autorzy, zastanawiając się nad kształtem powojennej Europy, podkreślali, że główne zagrożenie dla pokoju jest związane $\mathrm{z}$ istnieniem państw narodowych, których celem jest zawsze imperializm, a najtatwiej go przeprowadzić drogq ekspansji. Wykazywali, że instytucja państwa i mit narodu odegrały już swoją dziejową rolę, a podtrzymywanie ich przy życiu grozi nieustanną europejską wojną domową i stagnacją rozwoju cywilizacyjnego ${ }^{17}$. Podobnie jak Einaudi, a także Lord Lothian oraz Robbins ${ }^{18}$, Spinelli i Rossi podkreślali, że źródłem nacjonalizmu jest fuzja państwa i narodu, co wywołuje mieszankę wybuchową, rozbudzając tendencje autorytarne wewnątrz państwa i agresywne na poziomie międzynarodowym. Ich zdaniem faszyzm był jedynie końcowym stadium ewolucji historycznej państwa narodowego, wyrazem tendencji militarystycznych oraz autorytarnych, które dojrzały w strukturze zamkniętej państwa narodowego i uaktywniły się w walce o panowanie w Europie. Autorzy Manifestu twierdzili jednocześnie, że reakcyjna, totalitarna cywilizacja znalazła główne oparcie w nazistowskich Niemczech, i stwierdzali, że ocalenie cywilizacji europejskiej leżało w rękach aliantów. W rozdziale pt. Zadania powojenne: jedność europejska Spinelli i Rossi, chociaż byli przekonani, że nieuchronny upadek reżimów totalitarnych będzie stanowił triumf tendencji demokratycznych, wykazywali jednak, że samo zwycięstwo nad totalitaryzmem nie doprowadzi do rozwiązania dawnych problemów Europy. W 1941 r. spodziewali się, że koniec konfliktu zbrojnego wywoła kryzys rewolucyjny, podobny do tego, który nastąpił po zakończeniu I wojny światowej, i stworzy okazję do wprowadzenia w życie radykalnych nowych projektów, a w szczególności utworzenia Stanów Zjednoczonych Europy, w miejsce dawnych, pozornie demokratycznych państw narodowych. Należy zaznaczyć, że Spinelli sformułował wskazówki techniczne dotyczące kształtu przyszłej federacji europejskiej w artykule pt. Stany Zjednoczone Europy a różne kierunki politycz$n e$, który również został opracowany w czasie jego zesłania na wyspę Ventotene i dołą-

15 Głównym organem Europejskiego Ruchu Federalistycznego było pismo „L’Unità Europea”, które ukazywało się w tajnym obiegu od maja 1943 r. do lutego 1945 r. Współpracowali z nim Altiero Spinelli, Ernesto Rossi, Eugenio Colorni, Leone Ginzburg i Mario Rollier.

16 Ostatnie poprawki do Manifestu Rossi i Spinelli nanieśli po inwazji Niemiec na ZSRR, latem $1941 \mathrm{r}$. Zob. P. Graglia, Altiero Spinelli, Bologna 2008, s. 146.

17 Zob. P. Podemski, Wtoscy ojcowie zatożyciele Wspólnoty Europejskiej w kontekście transformacji Wtoch od faszyzmu do demokracji (1941-1954), Warszawa 2012, s. 22, Zeszyt - Centrum Europejskie Natolin, z. 47.

18 Zob. Lord Lothian, Il pacifismo non basta, Bologna 1986, Biblioteca Federalista; L. Robbins, Leconomia pianificata e l'ordine internazionale, Milano 1948, Politeia. 
czony do drugiego wydania Manifesto. Postulował w nim nadanie władzy federalnej takich kompetencji, które pozwoliłyby na utrzymanie w ryzach narodowych egoizmów, a zarazem zapewnienie ochrony mniejszościom etnicznym.

W koncepcji Spinellego przyszła wspólnota miała posiadać także uprawnienia do powoływania i organizacji sił zbrojnych, emisji wspólnej monety europejskiej, prowadzenia polityki zagranicznej oraz kształtowania granic administracyjnych państw członkowskich. Miała także zapewnić pełną swobodę przemieszczania się wszystkim obywatelom w ramach federacji. Warto zauważyć, że dopiero w 1945 r. Spinelli zaczął zastanawiać się nad praktycznym sposobem realizacji tego projektu. Zafascynowany pismami federalistów amerykańskich i metodą konstytuanty zastosowaną w czasie konwencji filadelfijskiej w 1787 r., stwierdzał, że musi być to proces demokratyczny, prowadzący do stworzenia nowej władzy federalnej, na poziomie ogólnoeuropejskim i ponadnarodowym, przy pełnym poparciu poszczególnych państw członkowskich, stopniowo rezygnujących ze swojej suwerenności, tak jak nastąpiło to przy tworzeniu Stanów Zjednoczonych Ameryki ${ }^{19}$.

W trzecim rozdziale autorzy Manifestu Spinelli i Rossi przedstawili listę koniecznych reform społecznych uzasadniających w praktyce projekt jednoczenia Europy. Postulowali w szczególności zniesienie własności prywatnej, nacjonalizację strategicznych gałęzi produkcji, przeprowadzenie reform rolnych i redystrybucję ziemi, zagwarantowanie powszechnego dostępu do edukacji dla młodzieży, a wszystkim Europejczykom minimalnego standardu życia, niezbędnego do zachowania ludzkiej godności, a także swobody zrzeszania się. Najbardziej kontrowersyjny okazał się punkt dotyczący zrównania w prawach wszystkich wyznań religijnych poprzez zniesienie paktów laterańskich. Faktem jest, że ta propozycja, a także inne negatywne wypowiedzi twórców Manifestu o Kościele katolickim jako sojuszniku reżimów reakcyjnych, wykopały przepaść pomiędzy federalistami z Ventotene a federalistami związanymi z Chrześcijańską Demokracją, którzy tworzyli koncepcje integracyjne w oparciu o Kościół i tradycję chrześcijańską. Jak zauważył Piotr Podemski, wspomniany rozdział zdradzał też lewicową formację intelektualną jego twórców ${ }^{20}$. Faktycznie przedstawiony w Manifeście program reform społecznych, mających na celu ochronę wolności jednostki i sprawiedliwości społecznej, połączony z negacją własności prywatnej przy jednoczesnym odrzuceniu sowieckiego kolektywizmu integralnego, a w szczególności idei upaństwowienia wszystkich środków produkcji, wykazuje wiele wspólnych punktów z programem Carlo Rossellego zawartym w Socialismo liberale. Należy jednak pamiętać, że Spinelli dokonał rozrachunku ze swoją marksistowską przeszłością w innym artykule, pochodzącym również z lat 1941-1942, a mianowicie Polityka marksistowska i polityka federalistyczna, w którym podkreślił m.in., że socjalizm w praktyce nie rozwiązuje problemów ludzi pracy, ponieważ po dojściu do władzy sytuacja materialna mas ulega zazwyczaj drastycznemu pogorszeniu. Jak zauważał, dopiero wyeliminowanie

9 Zob. A. Spinelli, Les tâches de la politique extérieure française, "Cahier de la Fédération Européenne” 1945, VIII.

20 P. Podemski, Wtoscy ojcowie zatożyciele Wspólnoty Europejskiej..., s. 22. 
szkodliwego rozdrobnienia społeczeństwa będzie mogło doprowadzić do emancypacji ludzi pracy, a optymalnym narzędziem likwidacji podziałów i ograniczeń miała być federacja europejska.

Manifest spotkał się z raczej chłodnym przyjęciem ze strony różnych odłamów opozycji antyfaszystowskiej. Odrzucenie zasady pełnej suwerenności narodu zostało zinterpretowane przez większość liberałów jako negacja jednej z głównych idei Risorgimenta, a mianowicie niezależności narodowej. Dla większości socjalistów transformacja poszczególnych państw w kierunku socjalistycznym miała doprowadzić automatycznie do stworzenia międzynarodowego systemu o charakterze pacyfistycznym i solidarnym, dlatego nie dostrzegali oni potrzeby tworzenia Stanów Zjednoczonych Europy. Jak wykazał Antonello Braga, już w okresie zesłania na Ventotene niektórzy przedstawiciele ugrupowania Giustizia e Libertà skrytykowali Manifest za „utopizm antyhistoryczny", nie zgadzając się z koncepcją wprowadzenia federacji drogą akcji rewolucyjnej oświeconej elity, bez odpowiedniego przygotowania świadomości mas $^{21}$. Manifest został też zdecydowanie odrzucony przez komunistów, którzy uważali federalizm za doktrynę reakcyjną, próbę odwzorowania na kontynencie europejskim systemu Stanów Zjednoczonych Ameryki oraz produkt międzynarodowego kapitalizmu ${ }^{22}$.

Pomimo dość krytycznych ocen różnych środowisk opozycji antyfaszystowskiej Manifest stał się inspiracją dla programu Europejskiego Ruchu Federalistycznego (Movimento Federalista Europeo - MFE), utworzonego w Mediolanie w dniach 27-28 czerwca 1943 r. przez grupę włoskich antyfaszystów pod przewodnictwem Altiero Spinellego i Ernesto Rossiego, a także dla zredagowanej w lipcu 1944 r. w Genewie Międzynarodowej Deklaracji Federalistyczneje ${ }^{23}$, która była pierwszym krokiem do założenia Unii Europejskich Federalistów (UEF) w Paryżu 15 grudnia 1946 r.

Podobnie jak w Manifeście, punktem wyjścia programu Movimento Federalista Europeo było przekonanie o kryzysie państwa narodowego, uważanego za źródło imperializmu i nacjonalizmu, które z kolei doprowadziły do powstania faszyzmu i nazizmu oraz wybuchu II wojny światowej. Założyciele MFE głosili także, że tylko federacja europejska i ograniczenie suwerenności poszczególnych państw narodowych będą mogły zagwarantować trwały pokój w Europie ${ }^{24}$. W centrum ich uwagi znalazła się również

21 Wspomniana krytyka doprowadziła do ostatecznego rozłamu Spinellego z grupą Giustizia e Libertà. Zob. L. Levi, Altiero Spinelli, fondatore del movimento per l'unità europea, [w:] A. Spinelli, E. Rossi, Il Manifesto di Ventotene, Milano 2006, s. 198.

22 Por. W. Lenin, Państwo a rewolucja. Nauka marksizmu o państwie i żadania proletariatu $w$ Rewolucji, [w:] W. Lenin, Dzieta wybrane, t. 2, Warszawa 1949, s. 153-252. Szerzej na ten temat zob. R. Monteleone, Le ragioni teoriche del rifiuto della parola d'ordine degli Stati Uniti d'Europa nel movimento comunista internazionale, [w:] L'idea dell'unificazione europea..., s. 76-95.

23 W czerwcu 1944 r. przedstawiciele ruchu oporu z Włoch, Francji, Holandii, Norwegii, Polski, Czechosłowacji, Jugosławii i Niemiec podpisali w Genewie Międzynarodową Deklarację Federalistyczną. Zob. Centre d'Action pour la Fédération Européenne, L'Europe de demain, Neuchâtel 1945, s. 68-75.

24 Należy zaznaczyć, że koncepcję tę rozwinął następnie Rossi w broszurce pt. Gli Stati Uniti d'Europa, opublikowanej w Szwajcarii w 1944 r. pod pseudonimem „Storno”, gdzie zastanawiając się nad zjawiskiem wojny totalnej, wykazywał, że jedynie stworzenie federacji europejskiej pozwoli wyeliminować 
kwestia Niemiec. Należy zaznaczyć, że ten problem był już podejmowany przez federalistów brytyjskich z grupy Federal Union, którzy na przełomie lat 30. i 40., licząc się z zakończeniem konfliktu zbrojnego, zastanawiali się, jak należy rozwiązać sytuację państwa, które ponosiło moralną odpowiedzialność za wybuch ostatniej wojny. Podobnie jak Lord Beveridge, również Spinelli i Rossi, wychodząc z założenia, że przyszła federacja miała być złożona wyłącznie z państw demokratycznych, uważali za stosowne reedukacje Niemców w kierunku demokratycznym i włączenie ich do wspólnoty europejskiej. Jak wykazywali, upokorzenie i przymusowe rozbrojenie Niemiec po I wojnie światowej nie przyniosło żadnych pozytywnych rezultatów. Jednocześnie zastanawiając się nad charakterem ruchu federalistycznego, Spinelli podkreślał, że musi być on ponadnarodowy i ponadpartyjny, skupiający wszystkich, którzy dążyli do federalistycznej przebudowy Europy, a także musi oddziaływać bezpośrednio na opinię publiczną. Jak stwierdził na spotkaniu założycielskim MFE: nie chcemy tworzyć partii federalistycznej [...]. Dla nas ważne jest, żeby ideologia federalistyczna nie byta blokowana przez inne partie. Jesteśmy ruchem, który nie chce konkurować z innymi partiami, lecz który chce od wszystkich uznania znaczenia federalizmu ${ }^{25}$.

Postanowienia konferencji w Jałcie i podział Europy na dwa wrogie obozy wydawały się klęską projektu budowy zjednoczonej Europy. W okresie bezpośrednio powojennym Spinelli porzucił Europejski Ruch Federalistyczny i podobnie jak Rossi ${ }^{26}$ podjął aktywną działalność w Partii Czynu (Partito d’Azione), ugrupowaniu, które najbardziej zaangażowało się w działalność na rzecz integracji europejskiej. Do kierownictwa w MFE powrócił dopiero po ogłoszeniu Planu Marshalla w 1948 r., do którego odniósł się pozytywnie. Był przekonany, że pojawiła się wówczas szansa zrealizowania programu federalizmu europejskiego z udziałem wyłącznie krajów demokratycznych Europy Zachodniej, w oparciu o Stany Zjednoczone Ameryki i w kontraście do imperialistycznej polityki ZSRR. W uroczystym przemówieniu wygłoszonym na I Kongresie Europejskiej Unii Federalistów w sierpniu 1947 r. stwierdził: Jeśli demokratyczna Europa nie ocali się sama poprzez skuteczne wysitki, czyniac użytek z oferowanej przez Amerykanów szansy, i nie zbuduje instytucji federalnych w sferze ekonomicznej i politycznej, to zwycięży amerykański imperializm. Federacja europejska, nawet jeśli tylko czę́ciowa, będzie niezależna od Ameryki w stopniu niemożliwym do osiagnięcia przez poszczególne państwa Europy Zachodniej. [...] Rozwiąanie federalistyczne [...] sprzeciwia się sowieckiemu imperializmowi z tych samych powodów co amerykańskiemu pluralizmowi ${ }^{27}$.

w przyszłości konflikty zbrojne. Jak pisał: obecnie wojna nie jest już starciem wojsk. Jest starciem się narodów, które w tej walce angażuja wszystkie swoje dobra i życie. Cyt. za: N. Bobbio, Il federalismo nel dibattito..., s. 223.

25 Zob. Protokót zatożycielski Movimento federalista Europeo. Cyt. za: L. Levi, Altiero Spinelli, fondatore del movimento..., s. 154.

26 Ernesto Rossi porzucił Movimento Federalista Europeo po odrzuceniu przez Zgromadzenie Narodowe Francji projektu zbudowania Europejskiej Wspólnoty Obronnej 30 sierpnia 1954 r.

27 Cyt. za: P. Podemski, Wtoscy ojcowie zatożyciele Wspólnoty Europejskiej..., s. 33. 


\section{PROGRAM FEDERALIZMU EUROPEJSKIEGO WŁOSKICH LIBERAŁÓW NA PRZYKŁADZIE KONCEPCJI LUIGIEGO EINAUDIEGO}

Pod wpływem myśli federalistów brytyjskich, przede wszystkim koncepcji Lorda Lothiana oraz Lionela Robbinsa, tworzył swoje idee także wspomniany już liberalny prawnik i ekonomista Luigi Einaudi ${ }^{28}$. Einaudi, który określany jest jako „federalista niezależny", pozostawał pod silnym wpływem liberałów angielskich, zwłaszcza ze szkoły manchesterskiej, a także koncepcji Richarda Cobdena oraz Johna Brighta i uważał Anglię za kolebkę zarówno liberalnej myśli politycznej, jak i nauk ekonomicznych. Jego koncepcje federalistyczne, opracowane już w okresie I wojny światowej, były związane $\mathrm{z}$ ideą zapewnienia trwałego pokoju na kontynencie europejskim po zakończeniu konfliktu zbrojnego. W artykule pt. La teoria inglese dell'equilibro europeo, który ukazał się 1 lutego 1917 r. w „Corriere della Sera”, Einaudi, rozpatrując kwestię angielskiej teorii równowagi sił, stwierdzał, że zbudowanie stabilnej równowagi w Europie odpowiadało interesom Anglii, ale było zarazem środkiem na zapewnienie trwałego pokoju, w interesie wszystkich państw, poza żywiącymi aspiracje hegemoniczne. Uzasadniał, że nie może istnieć w Europie jedno wielkie mocarstwo, lecz należy stworzyć federację różnych państw powiązanych wspólnymi ideatami i celami z Wielka Brytanią ${ }^{29}$. Podobnie też w artykułach opublikowanych w $1918 \mathrm{r}$. na łamach „Corriere della Sera”, podpisanych pseudonimem "Junius" i adresowanych do dyrektora gazety Luigiego Albertiniego, Einaudi podkreślał, iż trwały pokój można było utrzymać jedynie poprzez rezygnację $\mathrm{z}$ dogmatu suwerenności ze strony poszczególnych państw narodowych. Jednocześnie występował przeciwko projektowi utworzenia Ligi Narodów opartej na modelu konfederalnym, gdyż taka konstrukcja skazywała tę instytucję na bezsilność i pozbawiała ją autorytetu w stosunku do poszczególnych państw narodowych. W konsekwencji nie mogła stać się ona narzędziem do utrzymania stabilnego pokoju, lecz raczej zarzewiem konfliktów i niezgody pomiędzy członkami. Jak pisał w pierwszym artykule pt. La Società delle nazioni è un ideale possibile? z 5 stycznia 1918 r.: wysitki, żeby stworzyć ligę suwerennych narodów, postuża jedynie do ożywienia i pogtębienia konfliktów oraz wo$j e n^{30}$. Einaudi upatrywał słabości projektu w fakcie, że państwa stowarzyszone miały mieć zagwarantowaną pełną niezależność i suwerenność.

W przeciwieństwie do zwolenników projektu, przekonanych, iż Liga Narodów zapewni ciągły sojusz gwarantujący pokój pomiędzy członkami i obronę przed agresją zewnętrzną, akcentował, że będzie ona bezsilna wobec egoizmów narodowych poszczególnych państw członkowskich, protekcjonizmów gospodarczych, dążących do obrony

28 Luigi Einaudi (1874-1961) z wykształcenia był prawnikiem i ekonomistą, wykładał m.in. na uniwersytetach w Turynie i Mediolanie, od 1919 r. był senatorem, po II wojnie światowej został gubernatorem Banku Włoskiego, a w latach 1948-1955 był prezydentem Włoch.

29 Przedruk w: L. Einaudi, Cronache economiche e politiche, t. 4, Torino 1961, s. 765-767.

30 Zob. L. Einaudi, La società delle nazioni è un ideale possibile?, 5 I 1918, [przedruk w:] L. Einaudi, Lettere politiche di Junius, Bari 1920, s. 87, Politica ed Economia. 
produkcji narodowej oraz innych strategicznych interesów poszczególnych narodów. Ryzyko protekcjonizmu mogła przezwyciężyć jedynie federacja. Postulował jednocześnie stworzenie wspólnej armii europejskiej, której celem miało być zagwarantowanie pokoju wewnątrz federacji oraz jej obrona przed obcą agresją. Podobnie też w okresie międzywojennym krytykował bezsilność Ligi Narodów wobec powstających w Europie reżimów autorytarnych i totalitarnych. Należy zaznaczyć, że Einaudi, w odróżnieniu od innych liberałów, a w szczególności Francesco Saverio Nittiego, który w 1921 r. we wspomnianej już książce Europa senza pace stwierdzał, że Wielka Wojna zburzyła rodzącą się integrację gospodarczą w Europie, nie odrzucał a priori konfliktu zbrojnego. Jego zdaniem jedynie wojna prowadzona w słusznej sprawie mogła przyspieszyć powstanie Stanów Zjednoczonych Europy, a ostatni konflikt zbrojny stanowił milowy krok na drodze do zbudowania jedności wśród państw europejskich, połączonych ideą solidarności i poświęcenia dla wspólnej sprawy ${ }^{31}$. Rozważając model konfederalistyczny i federalistyczny, Einaudi wybierał zdecydowanie drugą opcję, podając jako przykład Stany Zjednoczone Ameryki, które po fazie konfederacji stały się federacją w oparciu o nową konstytucję z $1787 \mathrm{r}^{32}$ Jego zdaniem jedynie federacja mogła zapewnić swoim obywatelom stabilizację i rozwój, podczas gdy konfederacja była źródłem zamieszek, niepokojów oraz konfliktów społecznych. Jednocześnie wykluczał możliwość, żeby jedność Europy została przeprowadzona z inicjatywy ludu. Jego zdaniem był to proces stopniowy, który realizował się poprzez zjednoczenie państw powiązanych pomiędzy sobą przede wszystkim współpracą gospodarczą ${ }^{33}$.

Należy zaznaczyć, że po zakończeniu I wojny światowej Einaudi polemizował z projektem utworzenia Stanów Zjednoczonych Europy z wykluczeniem Wielkiej Brytanii, który proponowali inni liberałowie, w szczególności z koncepcją przemysłowca Giovanniego Agnellego oraz profesora ekonomii w Istituto Superiore di Commercio w Genui Attilo Cabiatiego, przedstawioną w książce pt. Federazione europea o Lega delle nazioni?, która ukazała się w $1918 \mathrm{r} .{ }^{34}$ Einaudi uważał, że federacja o takich rozmiarach byłaby zbyt wielka, ponieważ w jej granicach poszczególne narodowości odgrywałyby zbyt dużą rolę, a jednocześnie zbyt mała, gdyż wykluczając Anglię, byłaby ona zagrożona przez dominację Niemiec i mogłaby stać się rozszerzeniem

31 L. Einaudi, La pace e l'idea della guerra, „Corriere della Sera”, 1925, 23 V, [w:] L. Einaudi, Cronache economiche e politiche di un trentennio, Vol. 8, Torino 1965, s. 290-291. Należy zaznaczyć, że już w artykule pt. Un sacerdote della stampa e gli Stati Uniti europei, który ukazał się 20 sierpnia 1897 r. w „La Stampa”, Luigi Einaudi, recenzując artykuł Williama Thomasa Steada na temat wojny grecko-tureckiej z 1897 r., zgadzał się z redaktorem „Review of Reviews”, iż wspólna interwencja sześciu mocarstw mogła stanowić zalążek przyszłych Stanów Zjednoczonych Europy.

32 Zob. L. Einaudi, La Società delle Nazioni è un idea possibile?, [w:] L. Einaudi, La guerra el'unità europea, Bologna 1986, s. 20-21, Biblioteca Federalista.

33 W 1916 r., komentując artykuł prawnika Pietro Bonfantego, który postulował stworzenie trwałego przymierza pomiędzy Francją i Włochami jako podstawy przyszłej wspólnoty europejskiej, Einaudi podkreślał konieczność zawarcia unii celnej pomiędzy obydwoma państwami. Zob. L. Einaudi, Unioni politiche e unioni doganali, „Minerva” 1916, 1 II.

34 Recenzja Einaudiego opublikowana na łamach „La Riforma Sociale” 1918, Vol. 29, Terza Serie, s. 621-624, została przedrukowana w: L. Einaudi, Gli ideali..., s. 195-203. 
projektu Mitteleuropy ${ }^{35}$. Zdawał sobie jednak sprawę, że przystąpienie Wielkiej Brytanii do federacji niosłoby za sobą przyłączenie całego Commonwealthu, a także dostanie się w sferę wpływów federacji Stanów Zjednoczonych i Ameryki Łacińskiej. Stąd był on raczej zwolennikiem stworzenia kilku federacji państw opartych na kryteriach etnicznych i językowych: obok unii anglosaskiej miała powstać unia germańska, dwie słowiańskie oraz jedna łacińska, złożona z Włoch, Francji, Hiszpanii, a nawet krajów Ameryki Południowej.

Do kwestii federacji europejskiej Einaudi powrócił po upadku Mussoliniego w lipcu 1943 r. W opracowaniu pt. Per una federazione economica europea, które ukazało się z datą 15 września 1943 r. i zostało rozpowszechnione w tajnym obiegu przez Włoski Ruch Liberalny (Movimento Liberale Italiano), naszkicował zarys konstytucji przyszłej federacji, a zarazem podkreślał związki i wzajemne zależności pomiędzy sferą gospodarki i polityki. Zastanawiał się także, jaką rolę będą mogły odegrać Włochy w nowym układzie sił powojennej Europy. Zdając sobie sprawę, że jako sprzymierzeniec Trzeciej Rzeszy po zakończeniu wojny nie będą mogły uzyskać liczącej pozycji w przyszłej strukturze europejskiej, stwierdzał, że powinny odciąć się od polityki reżimu faszystowskiego i powrócić do liberalnej tradycji Risorgimenta, stając się rzecznikiem projektu federacji oraz ideałów wolności, równości i solidarności międzynarodowej ${ }^{36}$.

Koncepcję ścisłych relacji między gospodarką i polityką rozwinął także w broszurce opublikowanej w Szwajcarii pt. I problemi economici della federazione europea, w której uzasadniał, że stworzenie federacji było powodowane głównie względami ekonomiczny$\mathrm{mi}^{37}$. Należy podkreślić, że w latach 1943-1945 Einaudi, kreśląc wizję federalizmu europejskiego, wskazywał na model federalizmu szwajcarskiego, który uważał za lepszy od modelu amerykańskiego. Jak zauważał, w Szwajcarii trzy lub cztery narody współżyją w ramach jednej federacji, zachowują swój język i tożsamość, podczas gdy w Stanach Zjednoczonych po kilku pokoleniach potomkowie Anglików, Irlandczyków, Niemców, Skandynawów, Włochów i Słowian mieszają się, tworząc nowy naród. Kreśląc strukturę instytucjonalną przyszłej federacji, stwierdzał, że władza ustawodawcza powinna znajdować się w rękach dwuizbowego parlamentu, złożonego z Rady Państw, w której każde z państw członkowskich miało mieć równą liczbę przedstawicieli (jednego lub dwóch), i Rady Ustawodawczej, w której obywatele państw członkowskich byliby reprezentowani przez swoich deputowanych. Władzę wykonawczą sprawowałaby natomiast Rada Federalna, wybierana na wspólnym posiedzeniu obu Izb, a jej przewodniczącym miał być kolejno reprezentant każdego z państw członkowskich, zgodnie z modelem szwajcarskim. Projekt obejmował także stworzenie policji federalnej oraz sądownictwa federalnego. Zdaniem Einaudiego w kompetencji federacji powinny znajdować się: 1) swobodna wymiana towarów w obrębie państw członkowskich, 2) wspólna polityka migracyjna, 3) wspólna

35 Zob. C. Cressati, L'Europa necessaria. Il federalismo liberale di Luigi Einaudi, red. G. Giappichelli, Torino 1992, s. 54, Le Idee e le Istituzioni.

36 Tamże, s. 97.

37 L. Einaudi, I problemi economici della federazione europea, Lugano 1944, Movimento Federalista Europeo, 2 . 
polityka monetarna oraz 4) wspólna reglamentacja usług pocztowych, telegraficznych i telefonicznych, a także patentów, wag i miar. Liberalny polityk postulował też utworzenie wspólnego wojska europejskiego. Jak bowiem zauważał: federacja bytaby pustym stowem i ograniczytaby się do szkodliwej i nikomu niepotrzebnej Ligi Narodów, gdyby nie posiadata wtasnego wojska do obrony terytorium federacji przeciwko obcym agresjom i uniemożliwiajacym prowadzenie wojny wśród państw cztonkowskich ${ }^{38}$. Analizując przyczyny fiaska Ligi Narodów w okresie międzywojennym, dostrzegał on trzy zasadnicze powody: 1) była pozbawiona własnych dochodów i zależna od datków finansowych państw członkowskich, 2) nie posiadała własnego wojska i 3) nie miała władzy wykonawczej, a w podejmowaniu kluczowych decyzji była uzależniona od jednogłośności państw członkowskich $^{39}$. Jak stwierdzal, doświadczenie historyczne uczy, że ciato polityczne, które rodzi się stabe, nie może przeżyć i jest przyczyną któtni oraz zarzewiem wojen ${ }^{40}$. Zdaniem Einaudiego z przyszłej wspólnoty powinny być wykluczone Rosja Radziecka, której system polityczny i ekonomiczny zbyt różnił się od systemu polityczno-ekonomicznego federacji, a także Chiny i Japonia, jako zbyt odlegte i zbyt różne od Europy, oraz Stany Zjednoczone, które nie były gotowe zrezygnować z własnej autonomii politycznej i gospodarczej. Wykluczał także Wielką Brytanię, która - jak stwierdzał - już tworzyła własny konglomerat federa$\mathrm{cji}^{41}$. Jak zauważył włoski politolog Claudio Cressati, w 1944 r. Einaudi powielał projekt Agnellego i Cabiatego, który 25 lat wcześniej skrytykowal ${ }^{42}$.

Podobnie jak Spinelli i Rossi, również Einaudi uważał za głównego wroga idei federalizmu europejskiego ideę suwerennych państw narodowych: $Z$ tego ztowrogiego dogmatu - pisał - wywodza się monopolizmy narodowe, btędy autarkii, żądania elit rzadzacych do nieograniczonego rozporzadzania życiem i dobrami obywateli ${ }^{43}$. W artykule pt. Il mito dello stato sovrano z 3 stycznia 1945 r., który ukazał się w „Risorgimento Liberale”, liberalny polityk stawiał wręcz znak równości między ideą państwa suwerennego a walką o większą przestrzeń życiową ${ }^{44}$. Po powrocie do Włoch na przełomie grudnia $1944 \mathrm{r}$. i stycznia 1945 r. w artykule pt. Contro il mito dello Stato sourano opublikowanym w „Risorgimento Liberale" 3 stycznia 1945 r. oraz w mowie pt. La guerra e l'unità europea krytykował bezsilność Ligi Narodów w okresie międzywojennym i przedstawił swoją ideę suwerennego państwa narodowego jako gtównego nieprzyjaciela cywilizacji, inicjatora nacjonalizmów i podbojów $w^{45}$, zaś oparty na nim system europejski uważał za anachronizm historyczny. Postulował dobrowolną federację wolnych narodów w oparciu o unię celną. Jego zdaniem federacja gospodarcza miała być pierwszym krokiem do pełnej integracji

\footnotetext{
38 Zob. L. Einaudi, Per una federazione economica europea, [przedruk w:] L. Einaudi, La guerra e l'unità europea, s. 82.

39 Tamże, s. 70.

Tamże.

41 Tamże, s. 89.

42 Zob. C. Cressati, L'Europa necessaria..., s. 78.

43 Zob. L. Einaudi, Per una federazione economica europea, s. 95.

44 Przedruk w: L. Einaudi, La guerra e l'unità europea, s. 40-41.

45 L. Einaudi, Il mito dello stato sovrano, [w:] L. Einaudi, La guerra e l'unità europea, s. 40.
} 
politycznej oraz wojskowej. Należy zaznaczyć, że Einaudi obawiał się także, by przyszła federacja europejska nie powtórzyła błędów państw narodowych, tworząc nowy rodzaj „nacjonalizmu federalnego”. W liście z 8 listopada 1943 r. do Ernesto Rossiego pisał, iż ważne jest, żeby federacja europejska nie stata się narzędziem jednego państwa dominujacego, takiego, jakim byty „Pruskie Niemcy” Bismarcka; należy dbać o zachowanie suwerenności politycznej, religijnej i kulturalnej matych państw ${ }^{46}$.

\section{ZJEDNOCZONA EUROPA W KONCEPCJI ALCIDE DE GASPERIEGO I ŚRODOWISK KATOLICKICH}

Idee proeuropejskie w okresie Resistenza głosiły także środowiska katolickie, na czele z powstałą na przełomie 1942 i 1943 r. Chrześcijańską Demokracją (Democrazia Cristiana - DC). Należy zaznaczyć, że pierwsze teksty programowe DC raczej ogólnie podejmowały tematykę integracji, a zasadnicze znaczenie dla zrozumienia polityki partii w stosunku do idei zjednoczonej Europy miało stanowisko Piusa XII, który, powodowany silnym lękiem przed komunizmem, liczył na możliwość wcielenia w życie „katolickiego rozwiązania" moralnego kryzysu Europy, objawiającego się m.in. szerzeniem się prądów neopogańskich w latach 30. Papież kreował wizję „chrześcijańskiej Europy”, nawiązując do idei średniowiecznej Christianitas. W jego koncepcji jedynie religia chrześcijańska mogła stanowić inspirację dla nie tylko geograficznej, lecz także moralnej, politycznej oraz kulturalnej integracji w oparciu o dziedzictwo tacinskie ${ }^{47}$.

W okresie II wojny światowej zdecydowanie najdalej w deklaracjach proeuropejskich wybiegło środowisko katolików z Włoch Północnych, tzw. grupa neogwelficka, która pod przewodnictwem Piero Malvestitiego (1899-1964), jednego z założycieli Chrześcijańskiej Demokracji, opracowała w lipcu 1943 r. tzw. Program mediolański. Autorzy programu, powołując się na autorytet papieża, postulowali stworzenie federacji państw europejskich oraz bezpośredniej reprezentacji tak obywateli, jak i rządów ${ }^{48}$. Rozważali zrównanie pod względem prawnym obywateli wszystkich państw, a także możliwość wyboru pomiędzy obywatelstwem narodowym a europejskim oraz ujednolicenie zasad rządzących gospodarką krajową i europejską.

Nieco odmiennie koncepcję zjednoczonej Europy postrzegał natomiast sekretarz Chrześcijańskiej Demokracji Alcide de Gasperi, bliski współpracownik księdza Luigiego Sturza ${ }^{49}$, w okresie międzywojennym prześladowany przez reżim faszystowski,

46 Zob. Carteggio fra Luigi Einaudi ed Ernesto Rossi (1925-1961), red. G. Busino, S. Martinotti Dorigo, Torino 1988, s. 134.

47 Zob. G. Formigoni, Un'Europa cattolica? I cattolici italiani e la costruzione europea, [w:] L'Italia nella costruzione europea. Un bilancio storico (1957-2007), red. P. Craveri, A. Varsori, Milano 2009, s. 356, Storia Internazionale dell'Età Contemporanea, 1.

48 Zob. P. Podemski, Wtoscy ojcowie zatożyciele Wspólnoty Europejskiej..., s. 50.

49 Alcide De Gasperi (1881-1954) urodził się w Trydencie jako poddany Monarchii Austro-Węgier. Ukończył Uniwersytet Wiedeński w 1905 r. i związał się z katolickimi związkami zawodowymi, a następnie z powstałą w 1919 r. Partią Ludową księdza Luigiego Sturza. W 1921 r. został wybrany posłem 
a w latach 1945-1953 premier Włoch. Część historyków łączy moment konwersji prointegracyjnej de Gasperiego dopiero z rokiem 1950 oraz wybuchem wojny koreańskiej i mobilizacją w celu obrony Europy przed spodziewaną agresją ZSRR ${ }^{50}$. Należy jednak pamiętać, że pierwsze koncepcje proeuropejskie przedstawił on już 2 listopada $1943 \mathrm{r}$. w artykule programowym DC pt. Idee odbudowy Chrześcijańskiej Demokracji (Idee ricostruttive della Democrazia cristiana). Występując pod pseudonimem „Demofilo”, de Gasperi głosił ideę samostanowienia narodów, a za podstawę przyszłego porządku międzynarodowego uznawał ideę wolności oraz solidarności. Podkreślał potrzebę ograniczenia suwerenności państw narodowych na rzecz stworzenia jak najszerszej solidarności pomiędzy wolnymi narodami. Zauważał, że w celu utrzymania pokojowych relacji pomiędzy narodami należy stworzyć instytucje o charakterze konfederacyjnym i zasięgu zarówno kontynentalnym, jak i interkontynentalnym ${ }^{51}$. Podobnie jak Einaudi, również sekretarz Chrześcijańskiej Demokracji dostrzegał słabość Ligi Narodów oraz fiasko prowadzonej przez nią polityki w okresie międzywojennym. Zauważał, że nowa wspólnota powinna posiadać funkcje „polityczno-rozjemcze”, do których zaliczał: 1) powoływanie trybunałów, 2) nadzorowanie powszechnego rozbrojenia oraz 3) rozstrzyganie sporów międzypaństwowych; a także „polityczno-gospodarcze”, to znaczy: 1) zarządzanie dawnymi koloniami na zasadzie „otwartych drzwi”, 2) gwarantowanie równego dostępu do surowców oraz 3) stopniową eliminację autarkii i protekcjonizmu ${ }^{52}$. W koncepcji

do parlamentu (kiedy oficjalnie Trydent na mocy traktatu w Saint-Germain został przyłączony do Italii). W dniu 20 maja 1924 r., po dymisji księdza Sturza w lipcu 1923 r. i okresie triumwiratu Giulio Rodinò, Giovani Gronchi, Giuseppe Spataro, został sekretarzem Partito Popolare Italiano. Po zabójstwie posła Matteottiego De Gasperi znalazł się wśród promotorów moralnego ruchu oporu - opozycji awentyńskiej. 9 listopada 1926 r. został, jak wszyscy posłowie opozycyjni, pozbawiony przez reżim faszystowski mandatu poselskiego, a kilka miesięcy później aresztowany na dworcu we Florencji i skazany na cztery lata więzienia. Został wypuszczony w 1928 r. na skutek osobistej interwencji biskupa Trydentu i króla Wiktora Emanuela III u duce. Po podpisaniu traktatów laterańskich Watykan zaproponował mu posadę bibliotekarza w Bibliotece Watykańskiej. Okupację nazistowską Rzymu De Gasperi przeczekał w Pałacu Propaganda FIDE przy placu Hiszpańskim. Był współtwórcą Komitetu Wyzwolenia Narodowego powstałego 9 września 1943 r. W utworzonym w czerwcu 1944 r. rządzie socjalisty Ivanoe Bonomiego De Gasperi otrzymał stanowisko ministra bez teki, później był szefem włoskiej dyplomacji w gabinecie Ferruccio Parriego z partyzanckiej Partii Czynu, a od grudnia 1945 r. przez osiem lat obejmował urząd premiera. Literatura na temat koncepcji federalistycznych De Gasperiego jest niezwykle bogata. Wśród najważniejszych opracowań należy wymienić: P. Craveri, Europeismo e federalismo nel pensiero e nell'azione di Alcide De Gasperi, [w:] L'Italia nella costruzione europea...; M.R. De Gasperi, P. Ballini, Alcide De Gasperi. Un europeo venuto dal futuro, Soveria Mannelli 2011; M. Cau, L'Europa di De Gasperi e Adenauer, Bologna 2011; E. Conze, G. Corni, P. Pombeni, Alcide De Gasperi. Un percorso europeo, Bologna 2005, Annali dell'Istituto Storico Italo-Germanico. Quaderno, 65; G. Audisio, A. Chiara, Twórcy zjednoczonej Europy. Robert Schuman, Konrad Adenauer, Alcide De Gasperi, Warszawa 2007; J. Andrzejewska, Alcide De Gasperi (1881-1954). Cztowiek wolności i demokracji, Łódź 2007.

50 Zob. G. Corni, P. Pombeni, La politica come esperienza della storia, [w:] E. Conze, G. Corni, P. Pombeni, Alcide De Gasperi. Un percorso europeo, s. 48; M.R. De Gasperi, L'Europa nel pensiero di De Gasperi, [w:] M.R. De Gasperi, De Gasperi e l'Europa, Brescia 1979, s. 7.

51 Demofilo [De Gasperi], Idee ricostruttive della Democrazia cristiana, VII 1943, [w:] Scritti politici di Alcide De Gasperi, red. P.G. Zunino, Milano 1979, s. 263, Scrittori Politici Italiani, 2.

52 W. Lipigens, W. Loth, Documents of the History of European Integration, Vol. 1, Berlin 1988, s. 504-505, European University Institute, Ser. B, 1,3. 
de Gasperiego silny nacisk w procesie odbudowy pokoju w Europie został położony na współpracę ze Stanami Zjednoczonymi i Wielką Brytanią. Jednocześnie zastanawiając się nad miejscem Włoch w Europie, już w 1943 r. polityk podkreślał, że powinny one odzyskać swoją niezależność i integralność narodowa, a także odegrać rolę pośrednika pomiędzy Europą Centralną i basenem Morza Śródziemnego przy współpracy Anglosasów, których uważał za naturalnych sprzymierzeńców pacyfistycznej odbudowy powojennej Europy ${ }^{53}$.W okresie bezpośrednio powojennym de Gasperi, już jako premier, uznał za priorytetową kwestię włączenia Włoch do wspólnoty międzynarodowej54.

De Gasperi, podobnie jak Spinelli i Einaudi, dostrzegał głównego wroga idei integracji europejskiej w nacjonalizmach. W krytyce państwa narodowego, a także w przekonaniu o potrzebie ścisłej współpracy ze Stanami Zjednoczonymi i przypisywaniu Wielkiej Brytanii ważnej roli w procesie odbudowy powojennej Europy chadecki polityk zbliżał się do myśli niemieckich przedstawicieli opozycji antyhitlerowskiej grupy Kreisauer Kreis z lat 1939-1944, a w szczególności do koncepcji Helmutha Jamesa von Moltkego ${ }^{55}$. Jednocześnie, będąc tak jak Schuman „człowiekiem pogranicza”, wyrosłym w austriackim Trydencie, rozumiał problem mniejszości etnicznych. Niezwykle znaczące są jego słowa wypowiedziane podczas spotkania z austriackim ministrem spraw zagranicznych Karlem Gruberem we wrześniu 1946 r., kiedy jako minister spraw zagranicznych Włoch miał rozwiązać problem niemieckiej mniejszości językowej w południowej Adydze. Stwierdził wówczas: Moją nadzieja jest, żeby Brenner nie byt symbolem dawnych konfliktów, lecz stat się pomostem porozumienia i wymiany dwóch cywilizacji ${ }^{56}$. Należy zaznaczyć, że już po formalnym objęciu władzy przez de Gasperiego, na pierwszym krajowym kongresie Chrześcijańskiej Demokracji 10 grudnia 1945 r. uchwalono deklarację przeciwko nieograniczonej suwerenności narodowej, która głosiła konieczność wspótpracy wolnych, niepodlegtych, suwerennych Wtoch z innymi mitujacymi pokój narodami. Podkreślono także, że stuszna obrona praw narodowych nie może być mylona z nacjonalistycznym i imperialistycznym egoizmem, a państwo winno w szczególności szanować religijne, jezykowe i kulturowe prawa mniejszości etnicznych.

Jak słusznie zauważyła włoska historyk Sara Lorenzini, idea Europy de Gasperiego to Europa demokratyczna, obca wszelkim radykalizmom, będąca częścią wielkiej tradycji

53 Demofilo, La parola dei democratici cristiani, „Il Popolo” 1943, 2 XI, [w:] Scritti politici di Alcide De Gasperi, s. 272.

54 Faktem jest, że już w 1943 r. De Gasperi został uznany przez Stany Zjednoczone za interlokutora w rozmowach nad kwestią odbudowy politycznej Włoch, a jako premier w mowie wygłoszonej w Cleveland, w czasie oficjalnej wizyty w USA na początku 1947 r., przedstawił Stany Zjednoczone jako wielką sitę moralną, ekonomiczną i polityczną oraz wzór do naśladowania dla Europy, gdzie duch wolności i religii współżyje $w$ wyższym systemie kolektywnym, który godzi i harmonizuje prawa jednostki z interesami każdego z panstw skonfederowanych. Zob. A. De Gasperi, L'Europa. Scritti e discorsi, Brescia 2004, s. 51, Pellicano Rosso. Nuova Serie, 21.

55 Już w 1941 r. von Moltke głosił, iż Wielka Brytania, dzięki uzyskanemu w czasie wojny prestiżowi, ponownie przejmie „duchowe przywództwo w świecie”. Szerzej na ten temat zob. T. Scheffler, Idea zjednoczenia Europy w myśli politycznej Kreisauer Kreis Helmutha Jamesa von Moltkego (1939-1944), „Studia nad Faszyzmem i Zbrodniami Hitlerowskimi” 1995, Vol. 18, s. 101-126.

56 Cyt. za: M.R. De Gasperi, De Gasperi e l'Europa, s. 21. 
chrześcijaństwa, a zarazem bastion kulturalny przeciwko komunizmowi sowieckiemu ${ }^{57}$. Lider DC był bliski koncepcjom europeistycznym Watykanu oraz środowisk katolickich, aczkolwiek odrzucał oskarżenia o ambicje budowy watykańskiej Europy, twierdząc, że nie można sprowadzać ducha Europy do samej tylko tradycji chrześcijańskiej ${ }^{58}$. Jak podkreślał, w cywilizacji europejskiej połączyły się elementy kultury Bliskiego Wschodu, starożytnej Grecji i Rzymu, afrykańskich wybrzeży basenu Morza Śródziemnego, a także germańskie i słowiańskie. W jego koncepcji Europa była syntezą różnych ideologii politycznych i nurtów filozoficzno-religijnych: obok dziedzictwa chrześcijańskiego nie negował wpływów liberalizmu i socjalizmu. Należy jednak pamiętać, że de Gasperi w „geografii europejskiej” brał jedynie pod uwagę Europę Zachodnią. Nie był przeciwny bliskiej współpracy z Wielką Brytanią, która jako kraj zachodnioeuropejski mieściła się w jego wizji Europy. Jego zdaniem przystąpienie Wielkiej Brytanii do wspólnoty otwierałoby ważne perspektywy dla Europy przede wszystkim w sferze gospodarczej. Należy tutaj jednak zaznaczyć, że de Gasperi wielokrotnie powtarzał, że Europa nie powinna być zredukowana do matej Europy Karolingów, niemniej jednak w swoich rozważaniach pomijał raczej kraje, które znalazły się po drugiej stronie żelaznej kurtyny. W odczycie wygłoszonym na Grandes Conférences Catholiques w Brukseli w dniu 20 listopada 1948 r. pt. Le basi morali della democrazia chadecki polityk stwierdził, że zjednoczenie Europy w celu utrzymania pokoju jest koniecznością, aczkolwiek należało uniknąć błędów strategicznych, które popełniono po I wojnie światowej. W szczególności trzeba było włączyć w proces zjednoczeniowy Niemcy, żeby uniknąć powstania sentymentów rewanżu i odwetu. Jak zauważył Podemski, de Gasperi opowiadał się konsekwentnie za uwzględnieniem Niemiec w planach europejskich na pełnych prawach, zarówno ze względu na głębokie poszanowanie dla kultury niemieckiej, jak i osobistą znajomość z Adenauerem jeszcze z czasów jego działalności w partii Centrum. Nie można jednak zapominać, że podobnie do kwestii Niemiec odnosili się Spinelli i Rossi, a także federaliści brytyjscy z grupy Federal Union.

Od końca lat 40. kwestia integracji europejskiej stała się jednym z głównych elementów myśli politycznej chadeckiego lidera. W artykule pt. L'Unione europea, opublikowanym w „Il Popolo” 20 lutego 1950 r., de Gasperi uznał zjednoczenie Europy za projekt konieczny i dojrzaty w czasie. Zauważył, iż należy działać na rzecz politycznej i gospodarczej unii, gdyż tylko integracja europejska może rozwiązać problemy wewnętrzne Włoch, do których zaliczał w szczególności duży potencjał demograficzny, niedostatek surowców naturalnych i zacofany przemysł. Dużą wagę przywiązywał również do problemu emigracji, swobodnego przepływu ludzi i kapitałów oraz unii celnej. Niemiej jednak nie podzielał modelu federacji lansowanego przez MFE, podkreślając stopniowy charakter procesu integracyjnego oraz potrzebę znalezienia „rozwiązań przejściowych”. Popierał koncepcję wspólnoty europejskiej, realizowaną poprzez stopniową

Zob. S. Lorenzini, L'impegno di De Gasperiper un'Europa unita, [w:] E. Conze, G. Corni, P. Pombeni, Alcide De Gasperi. Un percorso europeo, s. 210.

58 Zob. D. Preda, Alcide De Gasperi federalista europeo, Bologna 2004, s. 164, Storia del Federalismo e dell'Integrazione Europea. 
integrację sektorową, przez co zbliżył się do programu funkcjonalistów. Podobnie jak Einaudi za motor integracji europejskiej uznawał aspekt ekonomiczny. Dał temu wyraz w 1949 r., stwierdzając: kiedy mówimy o wspótpracy europejskiej, mamy na myśli przede wszystkim wspótprace gospodarczą ${ }^{59}$.Zdaniem de Gasperiego Plan Schumana był pierwszym krokiem do nawiązania szerszej współpracy w materii nie tylko gospodarczej, lecz także politycznej. Podobnie też w 1951 r. pozytywnie odniósł się do Planu Plevena stworzenia wspólnego wojska europejskiego podlegającemu wspólnemu ministrowi obrony. Chociaż początkowo obawiał się, żeby nie stanął on na przeszkodzie Paktowi Atlantyckiemu ${ }^{60}$, doszedł do wniosku, że wojsko europejskie stanie się stabilnym pomostem pomiędzy różnymi narodami ${ }^{61}$. Pod koniec życia wielokrotnie podkreślał konieczność zbudowania unii europejskiej w kontekście solidarności atlantyckiej jako obrony przed „bolszewizacją” Europy. Na posiedzeniu Rady Europy w dniach 10-13 grudnia 1951 r., a następnie w mowie wygłoszonej w Akwizgranie 24 września 1952 r., z okazji otrzymania Medalu Karola Wielkiego, będącego największym uznaniem jego zasług $\mathrm{w}$ procesie integracji europejskiej ${ }^{62}$, zaznaczył, że zjednoczenie kontynentu było wielkim celem politycznym, do którego należało stopniowo zmierzać, nie eliminując znaczenia państw narodowych, współpracując aktywnie ze Stanami Zjednoczonymi, w celu zagwarantowania pokoju, postępu i sprawiedliwości społecznej w Europie.

\section{PODSUMOWANIE}

Stworzone w okresie Resistenza federalistyczne wizje Europy Altiero Spinellego, Ernesto Rossiego, Luigiego Einaudiego i Alcide de Gasperiego, chociaż wyrastały z odmiennego podłoża ideologicznego, stały się inspiracją dla procesów integracyjnych

59 Tamże, s. 78.

60 Dyskusja wokół europejkkich sił obronnych toczyła się na konferencji w Santa Margherita Ligure (12-13 lutego 1951 r.), gdzie spotkali się De Gasperi, Sforza, Pleven i Schuman. Podobnie jak De Gasperi, Sforza popierał ideę stworzenia wojska europejskiego we współpracy z Francją, jako pierwszego kroku do wprowadzenia federalizmu europejskiego. Niemniej jednak we Włoszech obawiano się przede wszystkim ograniczeń finansowych nałożonych na parlamenty narodowe przez wspólny budżet wojskowy. W lipcu 1951 r., kiedy po dymisji Sforzy De Gasperi objął również stanowisko ministra spraw zagranicznych, Włochy poparły szkic traktatu o wojsku europejskim, który de facto pozbawiał parlamenty narodowe kontroli nad budżetem wojkkowym i ograniczał suwerenność w polityce zagranicznej. Dla Włoch zarysowała się perspektywa niemożliwości rozporządzania pomocą finansową ze strony USA, przy jednoczesnym braku gwarancji w kwestii emigracji, ochrony gospodarki, wpływu kapitałów, dostępu do rynków kolonialnych od wspólnoty. Jeden z głównych przeciwników projektu, Giovanni Malagodi, stworzył wówczas slogan „Nie chcemy umrzeć dla wspólnoty, w której nie możemy żyć”.

61 Tezy włoskie znalazły wyraz w słynnym art. 38 projektu EWO, gdzie była mowa, że przyszła struktura organizacji europejskiej miała być federacyjna lub konfederacyjna, wyposażona w zgromadzenie dwuizbowe i władzę wykonawczą.

62 Przegrany w wyborach parlamentarnych 7 czerwca 1953 r. De Gasperi zszedł ze sceny politycznej. Tuż przed śmiercią 19 sierpnia 1954 r. żałował, że nie udało mu się doprowadzić do końca batalii w sprawie ratyfikacji Europejskiej Wspólnoty Obronnej. Niecałe dwa tygodnie później francuskie Zgromadzenie Narodowe odrzuciło projekt EWO. 
realizowanych w praktyce po zakończeniu II wojnie światowej. Rozwijane przez wspomnianych polityków refleksje nad kryzysem państwa narodowego, będącego źródłem szkodliwego nacjonalizmu, imperializmu i faszyzmu, oraz przekonanie, że jedynie utworzenie federacji europejskiej, złożonej z państw demokratycznych, jest w stanie zagwarantować trwały pokój w Europie, przedstawione m.in. w Maniféscie z Ventotene, artykułach i mowach Einaudiego oraz de Gasperiego w latach 1943-1945, weszly na stałe do programów federalistycznych, począwszy od Europejskiego Ruchu Federalistycznego i Unii Federalistów Europejskich. Podobnie też kwestia europejskich sił zbrojnych znalazła wyraz w projekcie utworzenia Europejskiej Wspólnoty Obronnej (Plan Plevena), a przekonanie Einaudiego i de Gasperiego o stopniowym charakterze procesu integracji, a także ścisłych powiązaniach sfery gospodarczej i politycznej okazało się metodą zwycięską procesów integracyjnych lat 50., od Planu Schumana po Traktaty rzymskie.

\section{BIBLIOGRAFIA}

\section{Teksty źródłowe}

Carteggio fra Luigi Einaudi ed Ernesto Rossi (1925-1961), red. G. Busino, S. Martinotti Dorigo, Torino 1988.

Centre d'Action pour la Fédération Européenne, L'Europe de demain, Neuchâtel 1945.

De Gasperi A., L'Europa. Scritti e discorsi, Brescia 2004, Pellicano Rosso. Nuova Serie, 21.

Einaudi L., Cronache economiche e politiche, Vol. 4, Torino 1961.

Einaudi L., Cronache economiche e politiche di un trentennio, Vol. 8, Torino 1965.

Einaudi L., La guerra e l'unità europea, Bologna 1986, Biblioteca Federalista.

Einaudi L., Lettere politiche di Junius, Bari 1920, Politica ed Economia.

Einaudi L., I problemi economici della federazione europea, Lugano 1944, Movimento Federalista Europeo, 2.

Lenin W., Państwo a rewolucja. Nauka marksizmu opaństwie i żadania proletariatu w Rewolucji, [w:] W. Lenin, Dzieta wybrane, Vol. 2, Warszawa 1949.

Lord Lothian, Il pacifismo non basta, Bologna 1986, Biblioteca Federalista.

Robbins L., L'economia pianificata e l'ordine internazionale, Milano 1948, Politeia.

Scritti politici di Alcide De Gasperi, red. P.G. Zunino, Milano 1979, Scrittori Politici Italiani, 2.

Spinelli A., Come ho tentato di diventare saggio, Bologna 1987, Storia / Memoria.

Spinelli A., Il lungo monologo, Roma 1968.

Spinelli A., La rivoluzione federalista. Scritti 1944-1947, Bologna 1996.

Spinelli A., Una strategia per gli Stati Uniti d'Europa, Bologna 1989.

Spinelli A., La crisi degli stati nazionali, Bologna 1991.

Spinelli A., Rossi E., Il Manifesto di Ventotene, Napoli 1982.

\section{Opracowania}

Albertini M., Chiti-Batelli A., Petrilli G., Storia del federalismo europeo, Roma 1973. Andrzejewska J., Alcide De Gasperi (1881-1954). Cztowiek wolności i demokracji, Łódź 2007. 
Audisio G., Chiara A., Twórcy zjednoczonej Europy. Robert Schuman, Konrad Adenauer, Alcide De Gasperi, Warszawa 2007.

Bobbio B.N., Il federalismo nel dibattito politico e culturale della resistenza, [w:] L'idea dell'unificazione europea dalla prima alla seconda guerra mondiale, red. S. Pistone, Torino 1975, Studi / Fondazione Luigi Einaudi.

Borejsza J.W., Szkoty nienawiści. Historia faszyzmów europejskich 1919-1945, Wrocław 2000.

Braga A., Un federalista giacobino. Ernesto Rossi pioniere degli Stati Uniti d'Europa, Bologna 2007, Fonti e Studi sul Federalismo e sull'Integrazione Europea - CRIE. Ricerche di Storia.

Cau M., L'Europa di de Gasperi e Adenauer, Bologna 2011, Annali dell'Istituto Storico Italo-Germanico in Trento. Quaderni, 84.

Chiti-Batelli A., L'idea d'Europa nel pensiero di Altiero Spinelli, Manduria 1989, Italia e l'Europa, 15 .

Cofrancesco D., Il mito europeo del fascismo (1939-1945), „Storia Contemporanea” 1983, II.

Colombo A., Europeismo e federalismo nei movimenti della „Terza Forza”, [w:] A. Colombo, La resistenza e l'Europa. Atti del Convegno di studi storici, Como, 28-31 maggio 1983, Firenze 1984, Quaderni di Storia (Felice Le Monnier (Firm)), 65/9.

Conze E., Corni G., Pombeni P., Alcide De Gasperi. Un percorso europeo, Bologna 2005, Annali dell'Istituto Storico Italo-Germanico. Quaderno, 65.

Corni G., Pombeni P., La politica come esperienza della storia, [w:] E. Conze, G. Corni, P. Pombeni, Alcide De Gasperi. Un percorso europeo, Bologna 2005, Annali dell'Istituto Storico Italo-Germanico. Quaderno, 65.

Craveri P., Europeismo e federalismo nel pensiero e nell'azione di Alcide De Gasperi, [w:] L'Italia nella costruzione europea. Un bilancio storico (1957-2007), red. P. Craveri, A. Varsori, Milano 2009, Storia Internazionale dell'Età Contemporanea, 1.

Cressati C., L'Europa necessaria. Il federalismo liberale di Luigi Einaudi, red. G. Giappichelli, Torino 1992, Le Idee e le Istituzioni.

De Gasperi M.R., De Gasperi e l'Europa, Brescia 1979.

De Gasperi M.R., Ballini P., Alcide De Gasperi. Un europeo venuto dal futuro, Soveria Mannelli 2011.

Formigoni G., L'Europa vista dal Vaticano. De Gasperi commentatore della politica internazionale, [w:] E. Conze, G. Corni, P. Pombeni, Alcide De Gasperi. Un percorso europeo, Bologna 2005, Annali dell'Istituto Storico Italo-Germanico. Quaderno, 65.

Graglia P., Altiero Spinelli, Bologna 2008.

Kozub-Ciembroniewicz W., Doktryny wtoskiego faszyzmu i antyfaszyzmu w latach 1922-1939, Kraków 1992, Zeszyty Naukowe Uniwersytetu Jagiellońskiego, 1068, Prace z Nauk Politycznych, z. 45.

Landuyt A., Idee d'Europa e integrazione europea, Bologna 2004, Storia del Federalismo e dell'Integrazione Europea.

Levi L., Altiero Spinelli, fondatore del movimento per l'unità europea, [w:] A. Spinelli, E. Rossi, Il manifesto di Ventotene, Milano 2010, Classici del Pensiero Libero, 25.

L'idea d'Europa nel Movimento di Liberazione 1940-1945, red. G. Arfé, Roma 1986.

Lipigens W., Loth W., Documents of the History of European Integration, Vol. 1, Berlin 1988, European University Institute, Ser. B, 1,3. 
Lorenzini S., L'impegno di De Gasperi per un'Europa unita, [w:] E. Conze, G. Corni, P. Pombeni, Alcide De Gasperi. Un percorso europeo, Bologna 2005, Annali dell'Istituto Storico Italo-Germanico. Quaderno, 65.

Marszałek A., Z historii europejskiej idei integracji międzynarodowej, Łódź 1996.

Monteleone R., Le ragioni teoriche del rifiuto della parola d'ordine degli Stati Unit d'Europa nel movimento comunista internazionale, [w:] L'idea dell'unificazione europea dalla prima alla seconda guerra mondiale, red. S. Pistone, Torino 1975, Studi / Fondazione Luigi Einaudi.

Pistone S., La lotta del movimento federalista europeo dalla Resistenza alla Caduta della Comunità Europea di difesa nel 1954, [w:] I Movimenti per l'unità europea 1945-1954, red. S. Pistone, Milano 1998, Edizioni Universitarie Jaca. Storia, 92.

Pistone S., L'Italia e l'unità europea dalle premesse storiche all'elezione del Parlamento europeo, Torino 1982, Documenti della Storia, 32.

Podemski P., Wtoscy ojcowie zatożyciele Wspólnoty Europejskiej w kontekście transformacji Wtoch od faszyzmu do demokracji (1941-1954), Warszawa 2012, Zeszyt - Centrum Europejskie Natolin, z. 47.

Preda D., Alcide De Gasperi federalista europeo, Bologna 2004, Storia del Federalismo e dell'Integrazione Europea.

Scheffler T., Idea zjednoczenia Europy w myśli politycznej Kreisauer Kreis Helmutha Jamesa von Moltkego (1939-1944), „Studia nad Faszyzmem i Zbrodniami Hitlerowskimi” 1995, Vol. 18.

Varsori A., La Cenerentola d'Europa? L'Italia e l'integrazione europea dal 1947 a oggi, Milano 2010, Saggi / Rubbettino, 242.

Dr hab. Joanna SONDEL-CEDARMAS jest kierownikiem Zakładu Polityki i Kultury Krajów Śródziemnomorskich w Instytucie Europeistyki UJ. Specjalizuje się w problematyce systemów i doktryn antydemokratycznych XX wieku (ze szczególnym uwzględnieniem włoskiego faszyzmu i nacjonalizmu), doktryny federalizmu europejskiego, a także myśli i kultury politycznej współczesnych Włoch. Tym tematom poświęciła dwie monografie (Gabriele D’Annunzio. Uźródet ideologicznych wtoskiego faszyzmu, Kraków 2008 oraz Nacjonalizm wtoski. Geneza i ewolucja doktryny politycznej (1896-1923), Kraków 2013) oraz szereg artykułów opublikowanych w pracach zbiorowych i czasopismach naukowych w języku polskim, włoskim oraz angielskim. 